\title{
A study on biodegradation of coir pith using microbial consortium
}

\author{
Leishipem Ningshen and Thilagavathy Daniel \\ Department of Biology, Gandhigram Rural Institute-Deemed University, Gandhigram-624302, Tamilnadu, \\ India.
}

\begin{abstract}
In the present study attempt was made to biodegrade coir pith using suitable microbes and their consortium, isolated from the naturally decayed coir pith, From the total colony forming units isolated from old coir pith, seven bacterial and five fungal strains which showed predominant growth were selected and independently screened for predecomposition of water washed coir pith for a period of 30 days. Pleurotus sajor caju was also tested for predecomposition of coir pith. Based on the predigestion characteristics, two microbes i-e Isolate-6 (bacteria, Pseudomonas spp) and Isolate-8 (fungi, Aspergilus niger) were selected. The two selected isolates and Pleurotus sajor caju were mixed with each other into four types of microbial consortia and were used for predecomposition (30 days).
\end{abstract}

Keywords: Aspergilus niger, Coir pith, Pleurotus sajor caju, Pseudomonas spp and predecomposition.

\section{Introduction}

Coir pith is a by-product of coconut industry. The dust left behind after extracting long fibres from the husk of a coconut is known as cocopeat or coir dust. It is a fluffy and spongy material with significant water holding capacity (Meerow, A. 1995). Coir pith will not degrade by itself and will remain over the soil years together. When it is burnt, it is not destroyed completely. It emits smoke continuously for a long time, thereby pollute the environment and disposal problems. However at present the coir pith has now become a money spinner. Coir pith is used as a moisture conserving agent in rain fed agriculture. It is also used as mulch for selected agro crops as it has a very high (400-600 percent) water holding capacity (Savithri and Khan, 1994). In the present study coir pith samples were collected from Solavanthan, Madurai District, Tamil Nadu, India. and subjected for biodegradability using microbes.

\section{Materials And Methods}

\section{Enumeration of the microbial populations}

Samples of old coir pith dumped around the coir industry were separately collected from several points, mixed and transported to the laboratory and immediately used for the analysis of total colony forming units (CFU) of bacteria, fungi and actinomycetes and were enumerated using standard plate count method. (Daniel and Karmegam 2000 ;Parthasarathi and Ranganathan, 1998 and Subbarao, 1995). From among the several microbial colonies of bacteria, fungi and actinomycetes which grew in the respective medium, only seven bacterial and five fungal isolates which showed predominant growth were selected for further studies.

\section{Identification of the selected bacteria and fungi}

All the seven bacterial isolates ( Isolate 1 to Isolate 7) were identified through morphological and biochemical characteristics. (Apun et al., 2000; Manivanan and Daniel 2008 ). The test results were compared with Bergey's Manual of Determinative Systematic Bacteriology (Holt et al., 1994) and all the five fungal isolates ( Isolate 8 to Isolate 12) were identified based on their macroscopic and culture characteristics i.e., fungal colony growth in agar medium and microscopic characteristics of the hyphae and reproductive structures after staining with lactophenol cotton blue. (Alexopoulos and Mims, 1983; Aneja,2001; Daniel et al., 2008-a ).

\section{Screening of selected microbes for predigestion of coir pith}

The seven predominant colonies of bacteria and five predominant colonies of fungi were independently screened for predigestion of coir pith. The fungus, Pleurotus sajor caju is well known for the biodegradation of lignocelluloses and hence P.sajor caju was also selected as a member for the predigestion of coir pith.

\section{Predigestion of coir pith using microbes}

The washed fresh coir pith was drained and dried in shade for $24 \mathrm{~h}$ and separately mixed with the 12 selected strains of microbes and subjected to predigestion in rectangular plastic troughs of $45 \times 35 \times 15 \mathrm{~cm}$ size 
for one month. Turning of the substrate was carried out at three days interval. After $30 \mathrm{~d}$ the EC, $\mathrm{p}^{\mathrm{H}}$, temperature and colour of the predigestion coir pith were recorded and based on the changes, two microbes i-e Isolate-6 (bacteria) and Isolate-8 (fungi) and P.sajor caju (fungi) were selected for further study.

\section{Preparation of microbial consortium}

Isolate- 6 and Isolate- 8 which showed better predigestion ability and P. sajor caju were mixed with each other into four types of consortia as given in Table 1. P. sajor caju was procured from a local mushroom farm.

Table 1. Formulation of microbial consortia

\begin{tabular}{|c|l|}
\hline Formulated consortium & Microbes used for the consortium \\
\hline C-1 & Asp + Pleu $(1: 1)$ \\
\hline C-2 -3 & Asp + Pseu $(1: 1)$ \\
\hline C-4 & Pleu + Pseu $(1: 1)$ \\
\hline & Asp + Pleu + Pseu $(1: 1: 1)$ \\
\hline
\end{tabular}

Asp-Aspergillus niger, Pleu-Pleurotus sajor caju, Pseu- pseudomonas spp

\section{Results}

The organic wastes used for the present study include fresh coir pith and aged old coir pith . Attempt was made to predigest fresh coir pith using microbes and their consortium. The results of the enumeration of the microbial populations such as bacteria, fungi and actinomycetes from old age coir pith showed the dominance of bacteria $\left(230 \pm 1.05 \mathrm{~g}^{-1}\right)$ followed by actinomycetes and then fungi as shown in Table 2 .

Table 2.Total colony forming units of bacteria, fungi and actinomycetes observed in old coir pith.

\begin{tabular}{|c|l|l|}
\hline S.no & Microbes & CFU g $^{-1}$ \\
\hline 1 & Bacteria & $230.00 \pm 1.05$ \\
\hline 2 & Fungi & $190.00 \pm 2.10$ \\
\hline 3 & Actinomycetes & $220 \pm 2.05$ \\
\hline
\end{tabular}

The results of the biochemical characteristics and the identification of the seven predominant bacterial isolates are given in Table 3. These bacterial isolates were identified as Micrococcus spp, Streptococcus spp, Alcaligenes spp, Staphylococcus spp, Proteus spp, Pseudomonas spp and Bacillus spp.

Table 3. Biochemical characteristics and identification of the seven predominant bacteria isolated from old coir pith

\begin{tabular}{|c|c|c|c|c|c|c|c|c|c|c|c|c|c|}
\hline \multirow[b]{2}{*}{ S.No } & \multirow[b]{2}{*}{ Code no. } & \multicolumn{11}{|c|}{ Biochemical Characteristics } & \multirow[b]{2}{*}{$\begin{array}{c}\text { Identification result (Name of } \\
\text { the bacterial strain) }\end{array}$} \\
\hline & & 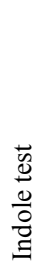 & 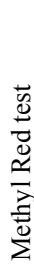 & 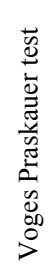 & 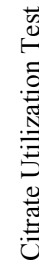 & 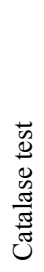 & 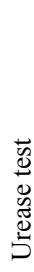 & 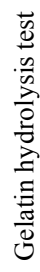 & 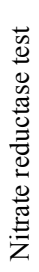 & 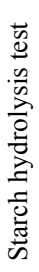 & 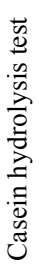 & 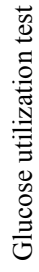 & \\
\hline 1 & Isolate 1 & + & + & - & - & + & - & + & - & - & - & + & Micrococcus spp \\
\hline 2 & Isolate 2 & + & - & - & + & - & + & - & + & - & - & + & Streptococcus spp \\
\hline 3 & Isolate 3 & + & + & + & + & + & - & + & - & - & - & - & Alcaligenes spp \\
\hline 4 & Isolate 4 & - & + & - & - & + & - & + & + & - & - & - & Staphylococcus spp \\
\hline 5 & Isolate 5 & - & + & - & - & - & + & + & + & - & - & + & Proteus spp \\
\hline 6 & Isolate 6 & + & - & - & - & + & + & + & + & - & - & - & Pseudomonas spp \\
\hline 7 & Isolate 7 & + & + & + & + & + & - & + & + & + & - & + & Bacillus spp \\
\hline
\end{tabular}

$+=$ Positive reaction $-=$ Negative reaction 
The morphological characteristics and the microscopic features of the five predominant fungal strains isolated from the old coir pith are given in Table 4. These colonies were identified as Aspergillus niger, Penicillium spp, Aspergillus flavus , Rhizopus spp and Trichoderma spp.

Table 4. Morphological characteristics of the five predominant fungi isolated from old coir pith

\begin{tabular}{|c|l|l|l|c|}
\hline S.No & Code no. & Colony morphology & Microscopic features & Identification result \\
\hline 1. & Isolate 8 & $\begin{array}{l}\text { Large cottony colony with } \\
\text { scattered black } \\
\text { spores }\end{array}$ & Conidia with spherical spores & Aspergillus niger \\
\hline 2. & Isolate 9 & $\begin{array}{l}\text { Greenish colony with radiated } \\
\text { ring }\end{array}$ & $\begin{array}{l}\text { Repeatedly branched } \\
\text { conidiospores with long chains } \\
\text { of spores }\end{array}$ & Penicillium spp. \\
\hline 3. & Isolate 10 & $\begin{array}{l}\text { Colony with yellow spore } \\
\text { with spherical spores }\end{array}$ & Aspergillus flavus \\
\hline 4. & Isolate 11 & $\begin{array}{l}\text { Cotton candy like colony, initially } \\
\text { white that turned grey to } \\
\text { yellowish brown in time. }\end{array}$ & $\begin{array}{l}\text { Non septate or sparsely septate } \\
\text { and broad conidium }\end{array}$ & Rhizopus spp \\
\hline 5. & Isolate 12 & $\begin{array}{l}\text { Light green colony with center } \\
\text { raised and smooth }\end{array}$ & Conidia in balls & Trichoderma spp \\
\hline
\end{tabular}

Table 5. The changes in electrical conductivity, $\mathbf{p}^{\mathrm{H}}$ and temperature of coir pith subjected to predecomposition using seven bacterial (30 d).

\begin{tabular}{|c|c|c|c|c|c|c|c|c|c|c|}
\hline \multirow[t]{3}{*}{ Sl.no } & \multirow[t]{3}{*}{ Microbes } & \multicolumn{9}{|c|}{ Parameters observed } \\
\hline & & \multicolumn{3}{|c|}{ EC } & \multicolumn{3}{|c|}{ pH } & \multicolumn{3}{|c|}{ Temperature } \\
\hline & & Od & $15 d$ & 30d & Od & 15d & 30d & Od & $15 d$ & 30d \\
\hline 1 & Micrococcus spp & 0.85 & 1.11 & 1.40 & 7.41 & 7.39 & 7.33 & 28.0 & 39.0 & 30.0 \\
\hline 2 & Streptococcus spp & 0.85 & 1.05 & 1.34 & 7.41 & 7.37 & 7.31 & 28.0 & 41.1 & 31.6 \\
\hline 3 & Alcaligenes spp & 0.85 & 1.03 & 1.32 & 7.41 & 7.38 & 7.32 & 28.0 & 40.0 & 30.8 \\
\hline 4 & Staphylococcus spp & 0.85 & 1.04 & 1.33 & 7.41 & 7.34 & 7.28 & 28.0 & 41.3 & 30.5 \\
\hline 5 & Proteus spp & 0.85 & 1.09 & 1.38 & 7.41 & 7.33 & 7.29 & 28.0 & 42.2 & 32.0 \\
\hline 6 & Pseudomonas spp & 0.85 & 1.20 & 1.54 & 7.41 & 7.31 & 7.26 & 28.0 & 44.5 & 29.0 \\
\hline 7 & Bacillus spp & 0.85 & 1.07 & 1.36 & 7.41 & 7.35 & 7.30 & 28.0 & 41.8 & 31.0 \\
\hline
\end{tabular}

Table 6. The changes in electrical conductivity, $\mathrm{p}^{\mathrm{H}}$ and temperature of coir pith subjected to predecomposition using five fungal isolates and Pleurotus sajor caju (30 d).

\begin{tabular}{|c|c|c|c|c|c|c|c|c|c|c|}
\hline \multirow[t]{3}{*}{ Sl.no } & \multirow[t]{3}{*}{ Microbes } & \multicolumn{9}{|c|}{ Parameters observed } \\
\hline & & \multicolumn{3}{|c|}{ EC } & \multicolumn{3}{|c|}{ pH } & \multicolumn{3}{|c|}{ Temperature } \\
\hline & & Od & 15d & 30d & Od & 15d & 30d & Od & 15d & 30d \\
\hline 1 & Aspergillus niger & 0.85 & 1.23 & 1.43 & 7.41 & 7.31 & 7.23 & 28.0 & 43.0 & 29.5 \\
\hline 2 & Penicillium spp. & 0.85 & 1.11 & 1.33 & 7.41 & 7.35 & 7.29 & 28.0 & 40.3 & 31.4 \\
\hline 3 & Aspergillus flavus & 0.85 & 1.19 & 1.39 & 7.41 & 3.37 & 7.31 & 28.0 & 39.5 & 31.5 \\
\hline 4 & Rhizopus spp & 0.85 & 1.12 & 1.31 & 7.41 & 7.36 & 7.30 & 28.0 & 39.0 & 31.3 \\
\hline 5 & Trichoderma spp & 0.85 & 1.18 & 1.38 & 7.41 & 7.33 & 7.28 & 28.0 & 41.0 & 30.3 \\
\hline 6 & Pleurotus sajor caju & 0.85 & 1.25 & 1.48 & 7.41 & 7.30 & 7.22 & 28.0 & 44.0 & 29.4 \\
\hline
\end{tabular}

Fig.1. The changes in electrical conductivity of coir pith subjected to predecomposition using four types of microbial consortia (30 d).

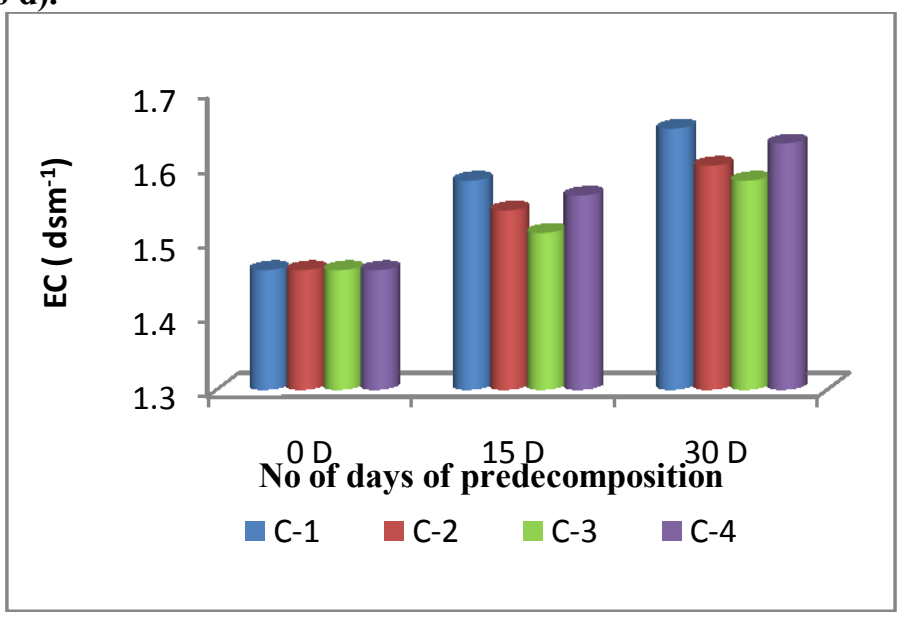


The electrical conductivity of the coir pith subjected to predecomposition using the four types of microbial consortia i.e. C1, C2, C3 and C4 are given in Fig.1. Consortium-1( A.niger + P.sajor caju) showed steady increase of electrical conductivity and gave highest value followed by $\mathrm{C} 4, \mathrm{C} 2$ and $\mathrm{C} 3(\mathrm{C} 1>\mathrm{C} 4>\mathrm{C} 2>\mathrm{C} 3)$.

Fig. 2. The changes in the $p^{\mathrm{H}}$ of coir pith subjected to predecomposition using four types of microbial consortia (30 d).

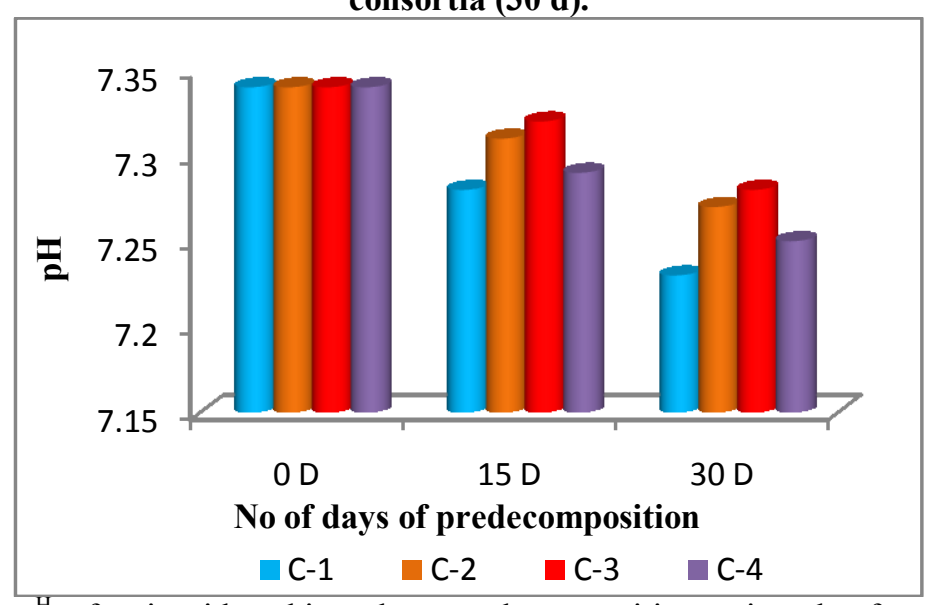

The $\mathrm{p}^{\mathrm{H}}$ of coir pith subjected to predecomposition using the four types of microbial consortia is shown in Fig.2. The $\mathrm{p}^{\mathrm{H}}$ steadily decreased with the increase in the number of days of decomposition. The best decrease was observed in $\mathrm{C} 1$ i.e. A.niger and P. sajor caju followed by $\mathrm{C} 4, \mathrm{C} 2$ and $\mathrm{C} 3(\mathrm{C} 1>\mathrm{C} 4>\mathrm{C} 2>\mathrm{C} 3)$.

Fig.3. The changes in the temperature of coir pith subjected to predecomposition using four types of microbial consortia ( $30 \mathrm{~d})$.

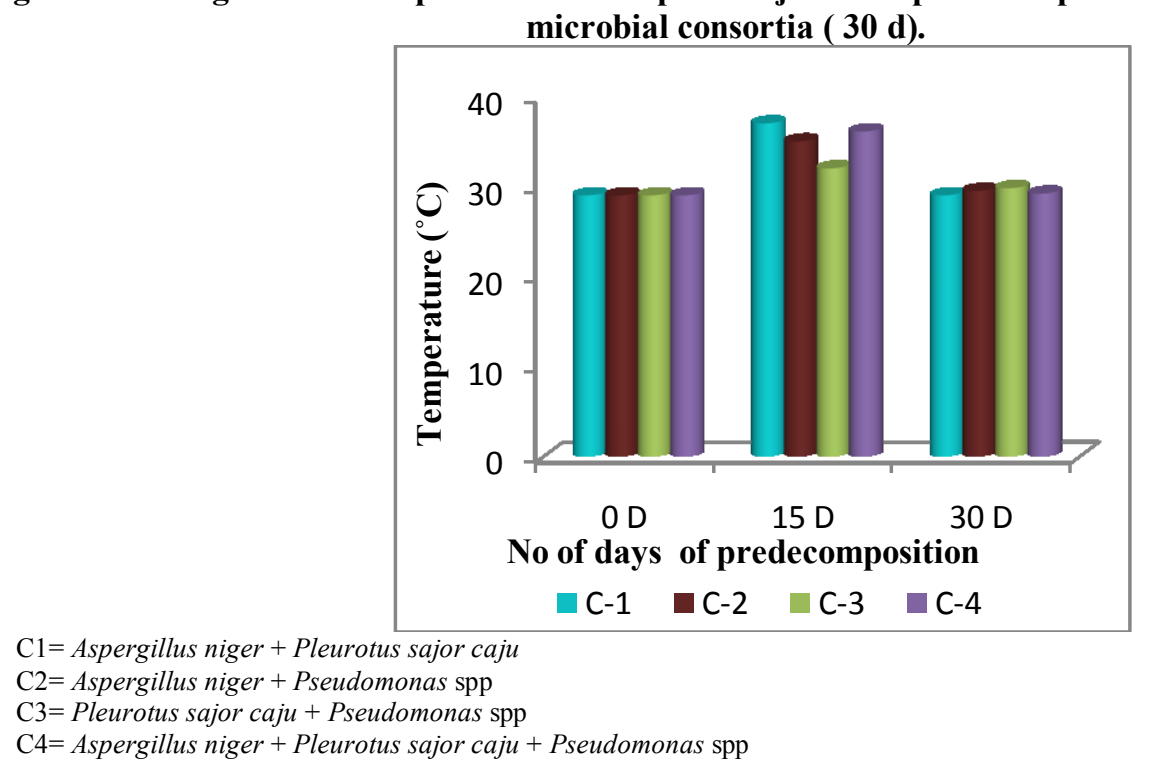

The temperature changes in coir pith subjected to predecomposition using the four types of microbial consortia is shown in Fig. 3. The temperature increased steadily from $29^{\circ} \mathrm{C}$ to $37^{\circ} \mathrm{C}$ upto 15 day and then the temperature declined to an average of $29^{\circ} \mathrm{C}$ on the 30 day.

The colour changes of coir pith subjected to predecomposition using four types of consortia are given in Table 7. The colour changed from creamy brown colour on the initial day to light brown and then to brown colour in all the four consortial treatments as given in Table 7. 
Table 7. The colour change of coir pith subjected to predigestion using four types of consortia (30 d).

\begin{tabular}{|c|c|c|c|c|}
\hline \multirow{2}{*}{$\begin{array}{l}\text { Formulated } \\
\text { consortium }\end{array}$} & \multirow{2}{*}{$\begin{array}{l}\text { Microbes used for } \\
\text { the consortium }\end{array}$} & \multicolumn{3}{|c|}{ Colour of coirpith } \\
\hline & & Initial day & $15 \mathrm{~d}$ & $30 \mathrm{~d}$ \\
\hline C-1 & Asp + Pleu (1:1) & Creamy & ++ & ++++ \\
\hline $\mathrm{C}-2$ & Asp + Pseu $(1: 1)$ & Creamy & + & +++ \\
\hline $\mathrm{C}-3$ & Pleu + Pseu $(1: 1)$ & Creamy & + & +++ \\
\hline $\mathrm{C}-4$ & Asp + Pleu $+P \operatorname{seu}(1: 1: 1)$ & Creamy & ++ & ++++ \\
\hline
\end{tabular}

$\mathrm{C} 1=$ Aspergillus niger + Pleurotus sajor caju

$\mathrm{C} 2=$ Aspergillus niger + Pseudomonas $\mathrm{spp}$

$\mathrm{C} 3=$ Pleurotus sajor caju + Pseudomonas spp

$\mathrm{C} 4=$ Aspergillus niger + Pleurotus sajor caju + Pseudomonas spp

$+=$ brownish cream, $++=$ very light brown, $+++=$ light brown, $++++=$ brown

\section{Discussion}

Generally coir pith is dumped around the coir industries, on the roadsides and in no-man's land and allowed to degrade over several years. It takes decades for decomposition because of its pentoson- lignin ratio less than 0.5 (Ramalingam et al., 2005). It is a rich source of potash. Also it helps to retain soil moisture for a longer period (Jothimani,1994). It can retain 5-6 times its weight of water. It is a good mulching agent.In the present study all the seven predominant bacterial isolates and all the five predominant fungal isolates selected from the naturally degraded coir pith and the fungus P.sajor caju were independently screened for predecomposition for a period of 30 days. During the 0,15 , and 30 day observation, the electrical conductivity increased with the increase in the number of days of predecomposition (Fig.1) and in all the treatments with the seven bacterial isolates (Table 5) and with the five fungal isolates ( Table 6). This observation shows that these microbes carry the necessary enzymes for the biodegradation of coir pith. Nagarajan et al (1985)also found that the inoculation of coir pith with Pleurotus spp had resulted in drastic reduction in lignin content and cellulose content indicating the degrading of lignocelluloses by Pleurotus sp, and hence it was included in the present study for biodegradation of coir pith. The $\mathrm{p}^{\mathrm{H}}$ steadily decreased with the increase in the number of days of predecomposition (Fig.2) and in all the treatments of seven bacterial isolates and the five fungal isolates. The shifting of $\mathrm{p}^{\mathrm{H}}$ to lower levels could be attributed to mineralization of nitrogen and orthophosphates and bioconversion of organic materials into intermediate species of organic acids ( Ndegwa et al., 2000). Temperature is one of the key indicators for microbiological reactions of predecomposition processes. Elevated temperature is necessary to destroy pathogens and other organic materials. The temperature changes in the all treatments with the selected seven bacterial, the five fungal isolates and with the four types of consortium (Fig 3) has enabled the conditions suitable for the aerobic microbes to proliferate in the present study. The effect of pre-decomposition of various organic wastes before vermicomposting has already been reported by several authors (Karmegam and Daniel, 2000-a, and Gajalakshmi et al., 2002-b). Colour has been described as a physical parameter to assess the maturinity and stability of predecomposition. Table 7 shows that 30 day predecomposition was sufficient for further vermicomposting. Matured compost shows a dark brown or almost black color and has a friable structure. The presence of mycelium (fungal growth) is evidence of a poor composting process (Inbar et al., 1990). It is generally suggested that as the compost stabilizes, it darkens to a dark brown or black color (Vuorinen and Saharinen, 1999).

\section{Conclusion}

India is a developing country and plenty of organic wastes are present in India. Animal wastes, agricultural residues, weeds, agroindustrial wastes and bio-municipal solid wastes are abundantly present in India. But most of these wastes are not properly used. There is a possibility of using all these wastes for the production of organic manure by different methods. Coir pith is one such organic waste which is not properly processed and recycled in India. This study is aimed at developing a technology for rapid degradation of coirpith and enrichment using microbes.

\section{Acknowledgement}

The authors greatly thankful to the University Grant Commission (UGC) for granting a financial assistance under RGNSRF for research work. 


\section{References}

[1]. Alexopoulos, C.J. and Mims, C.W. 1983. Text Book on Introductory Mycology. Wiley eastern Ltd., New Delhi.

[2]. Aneja, K.R. 2001. Experiments in Microbiology, plant pathology, tissue culture and mushroom production technology. New age International publishers, New Delhi. Pp. 282-291.

[3]. Apun, K., Jong, B.C. and Salleh, M.A. 2000. Screening and isolation of a cellulolytic and amylolytic Bacillus from sago pith waste. J. Gen. Appl. Microbial. 46:263-267.

[4]. Daniel, T. and Karmegam, N. 2000. Bio-conversion of selected leaf litters using an African epigeic Earthworm, Eudrilus eugeniae. Ecol.Env. and Cons. 5 (3):273-277.

[5]. Gajalakshmi, S., Ramasamy, E.V. and Abbasi, S.A. 2002-b. High-rate composting vermicomposting of water hyacinth (Eichornia crassipes, Mart.Solms). Bioresource Technology. 83:235-239.

[6]. Holt, J.G., Krieg, N.R., Sneath, P.H.A., Staley, J.T. and Williams, S.T. 1994. Bergey's Manual of determinative bacteriology. Lippincott Williams and Wilkins, A. Wolters Kluwer company, Philadelphia.

[7]. Inbar, Y., Chen, Y., Hadar, Y., Hoitink, H.A.J., 1990. New approaches to compost maturity. BioCycle 31, 64-69.

[8]. Jothimani, S. 1994. Organic farming in coconut. Indian Coconut Journal, 48-49.

[9]. Karmegam, N. and Daniel, T. 2000-a. Decomposition of leaf litters using the compost earthworm, Eisenia fetida. Indian J.Environ and Eco.Plan. 3(1):111-116.

[10]. Mahalingam, P.U. and Daniel, T. 2008-a. Gut microflora of earthworm, Eisenia fetida, Environment and Ecology. 26(1A):297-299

[11]. Manivannan, N. and Daniel, T. 2008. Organic waste recycling using Eudrilus eugeniae. Indian.J.Environ. and Ecology. 26(2):557559 .

[12]. Meerow, A. 1995. Growth of two tropical foliage plants using coir dusts as a container medium amendment. Hort Technology 5(3): 237

[13]. Nagarajan, R.; Manickam; T. S.; Kathandaraman G. V., Ramaswamy, K., and Palaniswamy, G.V., 1985 .Manurail of coir pith.. MadrasAgric. J. :72, 533-535.

[14]. Nedegwa, P.M. and Thompson, S.A. 2000. Effects of C to N ratio on Vermicomposting of biosolids. Bioresource Technology. 75:712.

[15]. Parthasarathi, K. and Ranganathan, L.S. 1998. Pressmud vermicasts the "hot spots" of fungi and bacteria. Ecol.Environ.Conser. 4:81-86.

[16]. Ramalingam, A., Gangatharan, M., Kasturi , R.2005. Solid state bio-treatment of coir pith and paddy straw. Asian Journal of Microbiology, Biotechnology and Environmental Science. 6:141-142

[17]. Savithri, P. and Khan, H. H. 1994. Characteristics of coconut coir pith and its utilization in agriculture. J. Plantation Crops. 22(1): $1-18$.

[18]. Subbarao, N.S. 1995. Soil microorganisms and plant growth. Oxford and IBH Publishing Co.Pvt.Ltd. (3 ${ }^{\text {rd }}$ edition). New Delhi.

[19]. Vuorinen, A. and Saharinen, M. 1999. Cattle and pig manure and peat cocomposting in a drum composting system: microbiological and chemical parameters. Compost Science \& Utilization. 7(3): 54-65. 